Advances in Gene Technology: The Genome and Beyond -

Structural Biology for Medicine (Proceedings of the 2002 Miami

Nature Biotechnology Winter Symposium)

TheScientificWorld 2002, 2(S2), 75-76

ISSN 1532-2246; DOI 10.1100/tsw.2002.36

\title{
HRAD30A, A GENE ENCODING A CLASS Y LOW-FIDELITY DNA POLYMERASE HAS A LOW COMPLEXITY REGION IN INTRON I ASSOCIATED WITH TISSUE- SPECIFIC ALTERNATIVE SPLICING
}

\author{
James E. Cleaver, Manish Thakur, Stas Volik, and Colin Collins \\ UCSF Cancer Center, University of California, San Francisco, CA 94143-0808 \\ jcleaver@cc.ucsf.edu
}

INTRODUCTION. The XP Variant (XPV) is a complementation group of the human disease xeroderma pigmentosum that was recently identified as a caused by mutations in a gene that maps to $6 p 21, h R a d 30 A$, that encodes a novel DNA polymerase, pol $\eta[1,2]$. Pol $\eta$ is a member of a large family, class $Y$, of low-fidelity DNA polymerases. It has the unusual property that although it can replicate UV-induced pyrimidine dimers in vivo with the insertion of the correct bases in the daughter strand, in vitro it is very error-prone and inserts mutagenic bases at about $1 \%$ frequency[3,4]. We recently identified an alternative splice variant of hRad30A mRNA in the testis and fetal liver, suggesting that there may be tissue-specific regulation of this gene[5]. This alternative splicing results in the elimination of exon II that contains the ATG start site for transcription and results in a cDNA that does not complement the XPV defect[5].

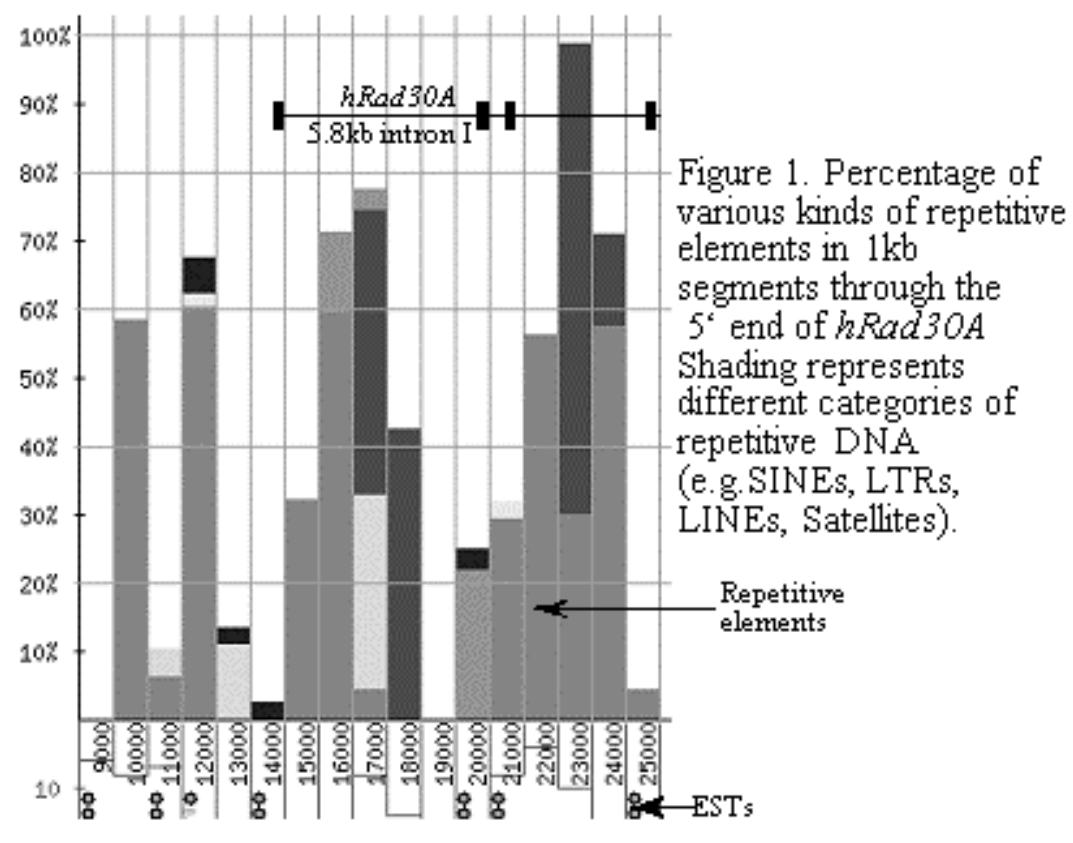

METHOD. hRad30A has 10 coding exons and an unexpressed exon I $5.8 \mathrm{~kb}$ upstream from the first coding exon. To investigate the basis for the alternative splicing we subjected the 5 ' end of 
the gene to analysis by a Genome Cryptographer (GC) program[6]. This is an exhaustive genome landscaping mapping that identifies repetitive element density and allows correlation between these elements and functional activity.

RESULTS AND DISCUSSION. GC analysis indicated that many of coding regions of $h$ Rad30A were regions of low complexity. This was anticipated since these should be informative for gene product synthesis and function. However, the long, $5.8 \mathrm{~kb}$ intron I also contained at least $1 \mathrm{~kb}$ of unique sequence with no detectable repetitive DNA, unlike the flanking regions, and a high frequency of $\mathrm{CpG}$ islands. This indicates that the intronic region has escaped invasion by repetitive DNA and probably contains important coding or regulatory regions. This region may therefore contain control elements for the tissue-specific splicing we previously observed (5), and will be the subject of further sequence and functional analysis.

ACKNOWLEDGEMENTS. Work supported by NIEHS grant number ES/CA08061 and the Ellison Foundation, with additional support from the XP Society.

\section{REFERENCES}

1. Johnson, R.E., Kondratick, C.M., Prakash, S., and Prakash, L. (1999) Science 264, 263-265.

2. Masutani, C., Kusumoto, R., Yamada, A., Dohmae, N., Yokol, M., Yuasa, M., Araki, M., Iwa, S., Takio, K., and Hanoaka, F. (1999) Nature. 399, 700-704.

3. Johnson, R.E., Washington, M.T., Prakash, S., and Prakash, L. (2000) Science 275, 7447-7450.

4. Matsuda, T., Bebenek, K., Masutani, C., Hanoaka, F., and Kunkel.T.A. (2000) Nature. 404, 1011-1013.

5. Thakur, M., Wernick, M., Collins, C., Limoli, C., Crowley, E., and Cleaver, J.E. (2001) Genes, Chrom. Cancer 32, 222-235.

6. Collins, C., Volik, S., Kowbel, D., Ginzinger, D., Ylstra, B., Cloutier, T., Hawkins, T., Predki, P., Martin, C., Wernick, M., Kuo, W.L., Alberts, A., and Gray, J.W. (2001) Genome Res. 11, 1034-1042. 

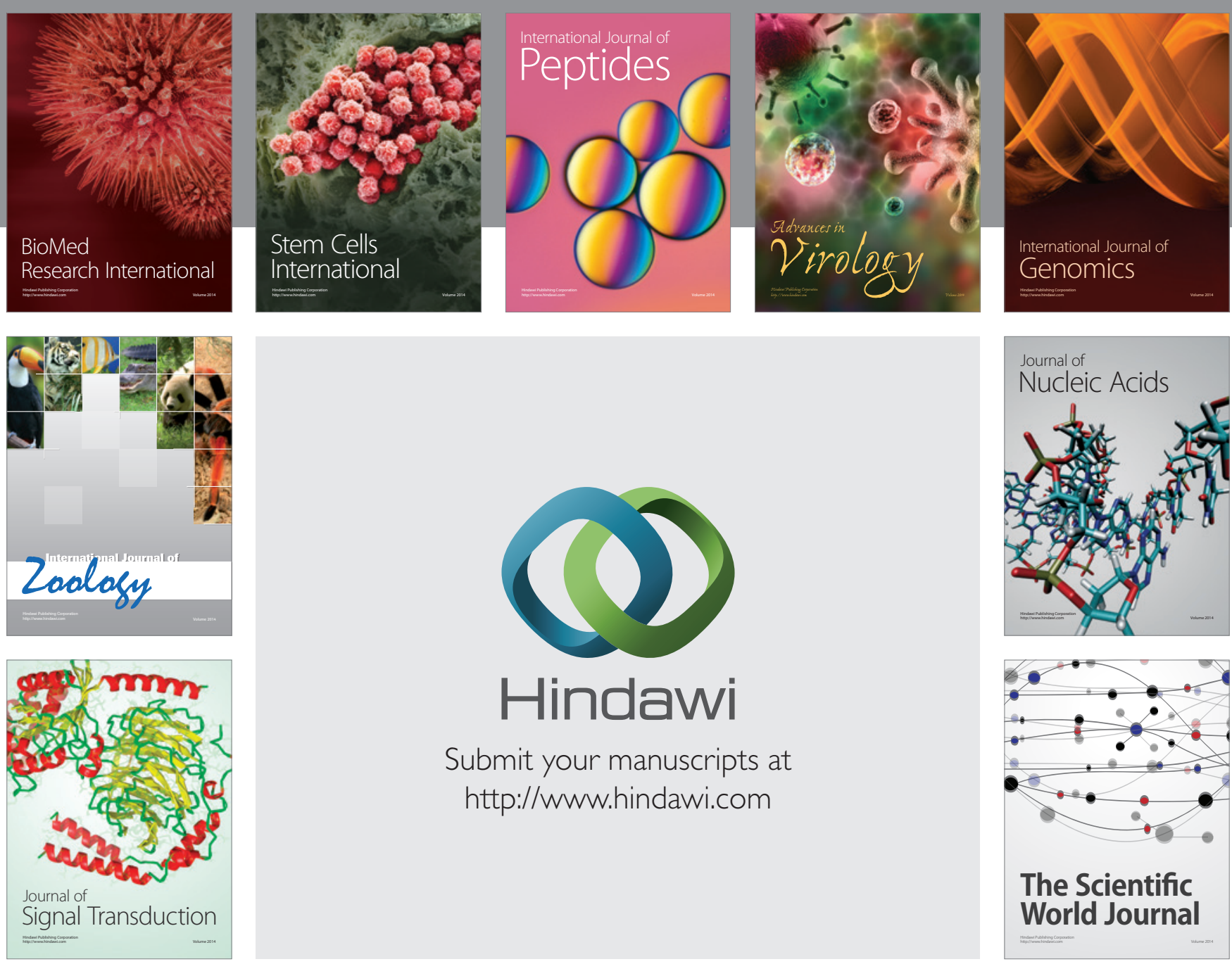

Submit your manuscripts at

http://www.hindawi.com
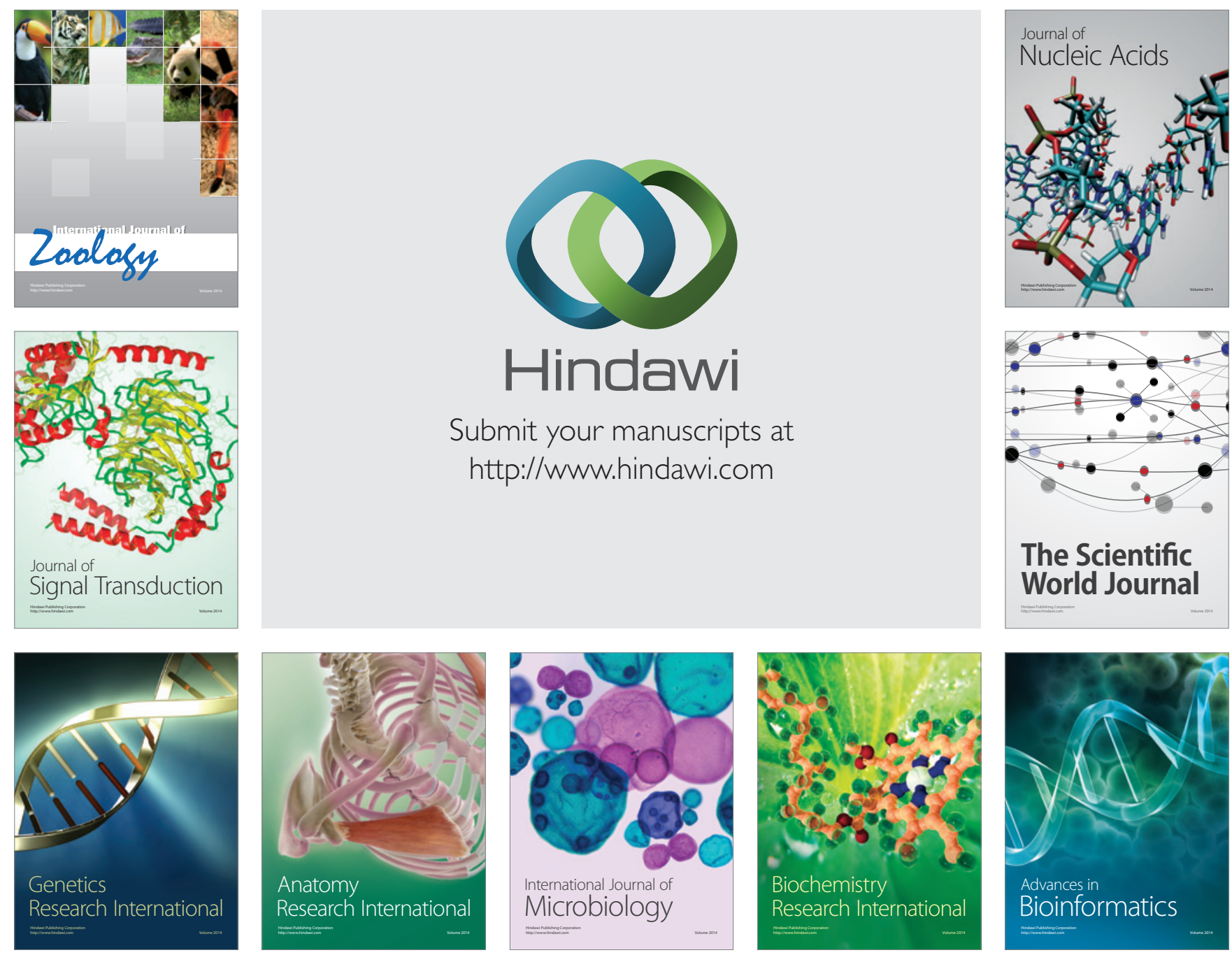

The Scientific World Journal
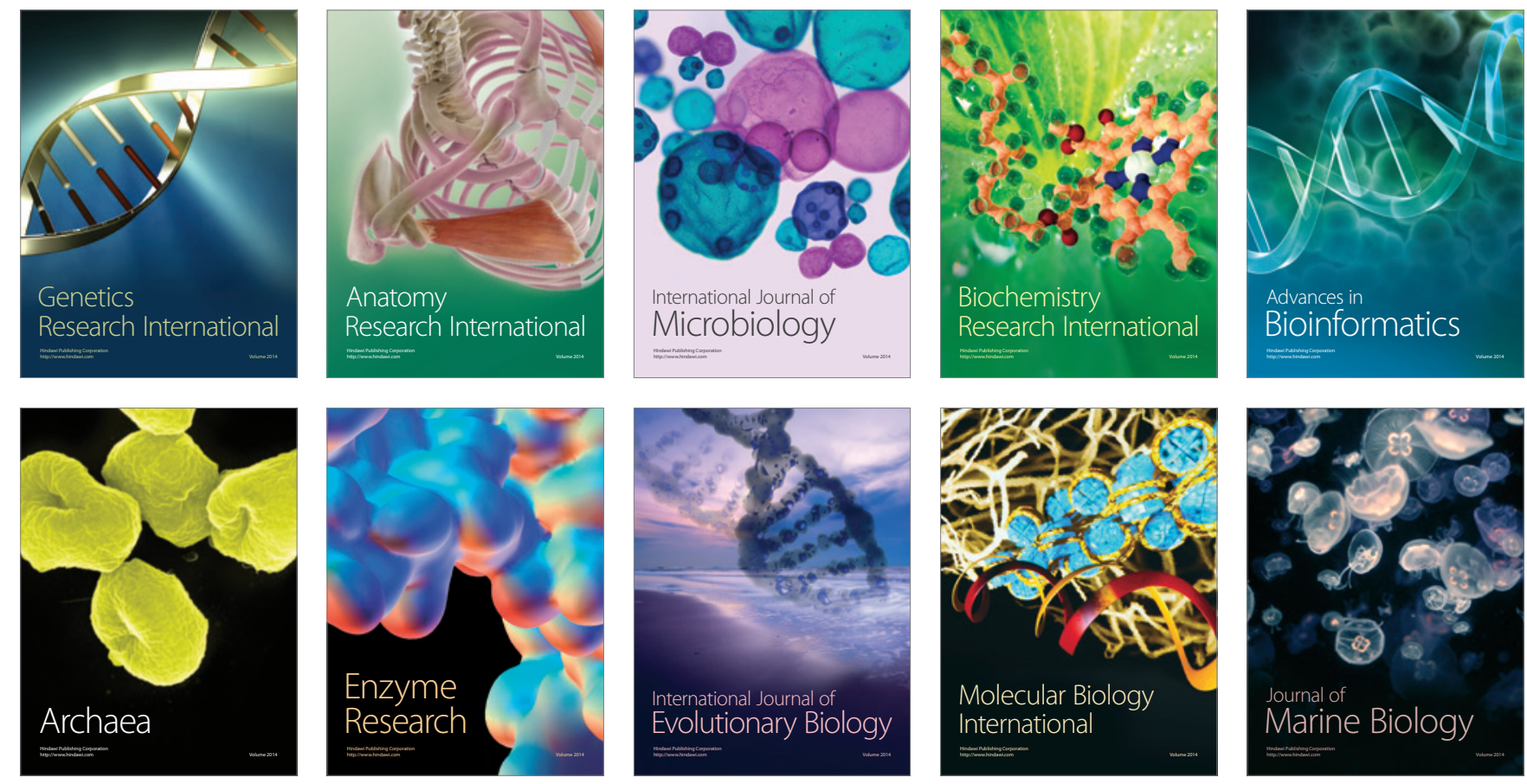